\title{
COVID-19. НАЙАКТУАЛЬНІША ПРОБЛЕМА СУЧАСНОСТІ
}

\section{В.І. Трихліб, Г.В. Осьодло}

\section{Українська військово-медична академія, м.Київ}

Вступ. На сьогодні, детальної інформації щодо інфікування військовослужбовців у доступних джерелах немає. В той же час $\epsilon$ інформація щодо можливого інфікування великої кількості військових, особливо тих, які знаходяться в умовах обмеженого простору. Актуальність даної інфекції для військових полягає і в тому, що під час призову на військову службу, при поверненні з відряджень і відпусток, дані категорії осіб (особливо які знаходяться в інкубаційному періоді або є безсимптомними) можуть занести пCоV 2019 у підрозділ та викликати спалах.

Мета роботи - вивчення та узагальнення досвіду фахівців з різних країн щодо актуальних питань захворювання COVID-19.

Матеріали та методи. За допомогою історичного, бібліосемантичного і порівняльного аналізу та системного підходу проведено узагальнення даних літератури стосовно етіологічних, епідеміологічних, клінічних і діагностичних аспектів нової коронавірусної інфекції, структури і частоти ускладнень.

Результати. У статті представлений огляд літератури з відображенням актуальності, етіології, епідеміології, клінічних проявів, діагностичних критеріїв COVID-19 та можливих ускладнень, які розвиваються при захворюванні з такою частотою: пневмонія (15,7-100\%), ГРДС (3-90\%), ураження серця (міокардит та ін.), аритмія, токсичний гепатит (4-53\%), реактивний панкреатит, тромбоз глибоких вен, тромбоемболія (до 31\%), коагулопатія (до 38\%), анемія (до 15\%), гостре ураження нирок 3 розвитком гострої ниркової недостатності (3-8\%), сепсис, септичний шок (4-8\%), поліорганна недостатність, отит, синусит, бронхіт, неврологічні ускладнення (36,4-45,5\%), гостре цереброваскулярне захворювання, інсульт, порушення свідомості, атаксія, судоми, невралгія, травмування скелетних м'язів, енцефалопатія, периферійна полінейропатія, вторинна бактеріальна інфекція (6-10\%), бактеріємія, грибкова суперінфекція, викидень (у 2\%), внутрішньоутробне обмеження росту (у 10\%), передчасні пологи (у $39 \%)$.

Висновки. У хворих із COVID-19 можуть розвиватися найрізноманітніші ускладнення, серед яких пневмонія, ГРДС, коагулопатія, тромбоемболія, ураження печінки. Тому у хворих зі швидким клінічним погіршенням слід виключати, крім розвитку ГРДС і легеневу тромбоемболію, в діагностиці якої важливу роль відіграють КТ-легенева ангіографія та додаткові лабораторні тести для дослідження системи коагуляції/антикоагуляції крові. Під час епідемічного періоду COVID-19, при обстеженні пацієнтів 3 неврологічними та іншими проявами, лікарі повинні розглядати інфекцію SARS-CoV-2 у якості диференційного діагнозу задля уникнення відстроченого чи помилкового діагнозу, запобігання передачі, попередження летальних наслідків, особливо, при важкому їі перебіг. Нова коронавірусна інфекція яскраво висвітлила проблеми, що можуть раптово і одночасно виникати в багатьох країнах світу, коли з'являються нові інфекції, особливо, у випадках нехтування елементарними заходами профілактики. COVID-19 продемонструвала, яку колосальну шкоду може принести економіці різних країн спалах інфекції протягом короткого часу. 3 урахуванням нових інфекцій, необхідно докорінно переглянути ставлення до профілактичної медицини, біобезпеки країни, інфекційних хвороб та організації надання медичної допомоги при інфекційних захворюваннях.

Ключові слова: COVID-19, етіологія, епідеміологія, клінічні прояви, ускладнення.

Вступ. До сімейства Coronaviridae належить шість відомих раніше РНК-вірусів, широко розповсюджених у людей та інших ссавців. Коронавіруси можуть викликати різноманітні захворювання як у людини, так і у тварин. Хоча чотири з цих коронавірусів викликають легкі респіраторні симптоми, подібні до звичайної застуди, епідемії, спричинені двома бетакоронавірусами, SARS-CoV у 2002 році та MERS-CoV у 2012 році, охопили понад 8000 пацієнтів та 1000 пацієнтів відповідно з високими показниками смертності $(10 \%$ для ГPBI-CoV i $37 \%$ для MERS-CoV). Відомо, що коронавіруси (CoV) можуть швидко адаптуватися і долати видовий бар'єр, наприклад, при SARS-CoV і близькосхідному респіраторному синдромі CoV (MERS-CoV), викликаючи епідемії або пандемії.

Новий коронавірус SARS-CoV-2 - сьомий член родини Coronaviridae, який, як відомо, заражає людей. Поки що рівень смертності від COVID-19 нижчий, ніж при коронавірусних 
захворюваннях на ГPBI-CoV або MERS-CoV. Однак SARS-CoV-2 є високоінфекційним і може становити значну загрозу здоров'ю населення різних країн.

Епідемія коронавірусної інфекції розпочалася з появи в Ухані (Китай) у грудні 2019 року багато незрозумілих випадків пневмонії, які в подальшому швидко поширилися по території Китаю та інших країн світу, в тім числі Європи, Північної Америки та Азії. При етіологічному розшифруванні встановлено, що цю епідемію спричинив новий $\mathrm{CoV}$, який викликає симптоми, що нагадують прояви важкого гострого респіраторного синдрому SARS-CoV (2003 p.) та MERS (2012р.). Дані збудники мали зв'язок із одним і тим же рецептором, ACE2. Тому цей вірус був названий SARS-CoV-2, а в подальшому ВООЗ назвала хворобою коронавірусів 2019 р. COVID-19.

На даний час $\epsilon$ інформація щодо існування трьох-чотирьох різновидностей вірусу, притаманних для різних територій і які, ймовірно, можуть сприяти особливостям перебігу коронавірусної інфекції в різних регіонах.

31 січня 2020 р. В003 оголосила про захворювання коронавірусною хворобою (COVID-19), як надзвичайну ситуацію у сфері охорони здоров'я, що має міжнародне значення. Було встановлено, що збудник SARS-CoV-2 має здатність до ефективної передачі від людини людині різними шляхами. Це значно ускладнює ситуацію серед різних груп людей: одних, які належать до груп високого ризику, щодо ускладненого та важкого перебігу, інших - стосовно підвищеного ризику інфікування (осіб із будинків для людей похилого віку, дитячих садків, школярів, студентів і, особливо, військовослужбовців, які можуть знаходитись тривалий час у замкнутих приміщеннях під час бойового чергування, у спальних приміщеннях, на кораблях та в умовах підвищеного скупчення). За деякими розрахунковими даними відсоток уражених у підрозділі може сягати до 10-20\%, що суттєво не відобразиться на боєздатності підрозділу [1]. На даний час $\epsilon$ випадки захворювань серед військовослужбовців у різних арміях і навіть спалахи. Так, станом на 7 травня у ЗС США зареєстровано 7702 випадки інфікування, 3 них 5086 військовослужбовців, з госпіталізацією 113 осіб [2]. Реально інфікованих може бути значно більше з урахуванням того, що не всі військовослужбовці пройшли обстеження.

На сьогодні, детальної інформації щодо інфікування військовослужбовців у доступних джерелах немає. В той же час $\epsilon$ інформація щодо можливого інфікування великої кількості військових, особливо тих, які знаходяться в умовах обмеженого простору. Актуальність даної інфекції для військових полягає і в тому, що під час призову на військову службу, при поверненні 3 відряджень і відпусток, дані категорії осіб (особливо які знаходяться в інкубаційному періоді або є безсимптомними) можуть занести nCoV 2019 у підрозділ та викликати спалах. Ускладнює ситуацію і те, що на даний час немає високочутливих тестів для ранньої діагностики, включаючи й ПЛР. Тому доцільно повернутись до досвіду радянської армії, коли призовників у військових частинах розміщували окремо у карантині (на місяць), де вони проходили адаптування до військової служби і навчалися. 3 власного досвіду, спостерігаючи за рівнем захворюваності серед військовослужбовців, хочемо відмітити, що частіше хворіють призовники протягом перших 2-х місяців після призову. Також з метою запобігання занесення й інших особливо-небезпечних інфекцій в Україну, карантин повинні проходити і миротворці.

«На жаль, у керівного складу різних рівнів і країн склалася думка про те, що інфекційні захворювання взяті під контроль і тому або були ліквідовані інфекційні відділення та органи профілактичної медицини, або їх скоротили до рівня, що вони не спроможні справлятися 3 проблемами, які раптово можуть виникнути. Натомість надали перевагу розвитку хірургічних відділень, для лікування опіків та поранень, отриманих під час військових конфліктів», зауважив у своїй статті полковник у відставці, воєнний хірург Томас Кребтрі. «Сьогоднішня криза має стати тривожним дзвінком, щоб переосмислити будь-які спроби скоротити військову медицину» - написали генерал-лейтенант ВПС у відставці Орвілл Райт і полковник ВПС у відставці Кіт Цугеля в своєму недавньому випуску «Military Times». «Наш народ опинився погано підготовленим до цієї пандемії. Нам не вистачає як обладнання, так і навченого персоналу, щоб ефективно реагувати». «Необдумані скорочення військової медицини, зазначили автори пізніше, - створюють ризики, які виходять далеко за рамки ЗС» [3]. 
Епідеміологічна картина щодо інфікованості, наслідків і летальності з приводу COVID-19 в різних країнах світу станом на 7.05.2020 р. представлена в таблиці 1 [4].

Дані, представлені у таблиці 1 потребують уточнення, в зв'язку з тим, що значна кількість інфікованих були безсимтомними або з незначно вираженими клінічними симптомами, із-за різних підходів до трактування випадку захворювання та зв'язку летального наслідку із COVID-19.

12 лютого Китай змінив своє визначення підтверджених випадків, включивши в нього і пацієнтів з негативними результатами тестів, але з наявними клінічними, рентгенологічними та епідеміологічними характеристиками COVID-19, що призвело до збільшення зареєстрованих випадків на 15000 за один день. Станом на 05.03.2020 р. було зареєстровано 96000 випадків по всьому світу (80 000 у Китаї) і у 87 інших країнах та в одному міжнародному перевезенні (696 осіб на круїзному судні Diamond Princess, припаркованому біля берегів Японії). В подальшому на фоні зменшення зареєстрованих випадків у Китаї, в інших країнах відмічається збільшення захворюваності в геометричній прогресії, включаючи Південну Корею, Італію, Іран та інші країни Європи і світу.

Таблиця 1

Дані CDC по країнах світу, станом на 7.05.2020 р.

\begin{tabular}{|c|c|c|c|c|}
\hline Країни & Інфіковано & Одужало & Померло & $\begin{array}{c}\text { Летальність } \\
(\%) \\
\end{array}$ \\
\hline Всього & 3820736 & 1303146 & 265094 & 7,0 \\
\hline США & 1263197 & 213109 & 74807 & 5,9 \\
\hline Іспанія & 253682 & 159359 & 25857 & 10,2 \\
\hline Iталія & 213013 & 85231 & 29315 & 13,8 \\
\hline Великобританія & 194990 & н/д & 29427 & 15,1 \\
\hline Pocig & 177160 & 23803 & 1625 & 0,9 \\
\hline Франція & 170551 & 52736 & 25531 & 15,0 \\
\hline Німеччина & 167239 & 137400 & 6993 & 4,2 \\
\hline Туреччина & 129491 & 73285 & 3520 & 2,7 \\
\hline Бразилія & 116299 & 48221 & 7966 & 6,8 \\
\hline IpaH & 101650 & 81587 & 6418 & 6,3 \\
\hline Китай & 82883 & 77911 & 4633 & 5,6 \\
\hline Канада & 62046 & 26993 & 4043 & 6,5 \\
\hline Бельгія & 50781 & 12731 & 8339 & 16,4 \\
\hline Пepy & 51189 & 15413 & 1444 & 2,8 \\
\hline Індія & 46437 & 12847 & 1566 & 3,4 \\
\hline Нідерланди & 40770 & н/д & 5082 & 12,5 \\
\hline Еквадор & 31881 & 3433 & 1569 & 4,9 \\
\hline Швейцарія & 29981 & 24500 & 1784 & 6,0 \\
\hline Сауд. Аравія & 28656 & 4476 & 191 & 0,7 \\
\hline Португалія & 25524 & 1712 & 1063 & 4,2 \\
\hline Мексика & 23471 & 13447 & 2154 & 9,2 \\
\hline Швеція & 22721 & 4074 & 2769 & 12,2 \\
\hline Ірландія & 21772 & 13386 & 1319 & 6,1 \\
\hline Пакистан & 20941 & 5635 & 476 & 2,3 \\
\hline Чілі & 20643 & 10415 & 270 & 1,3 \\
\hline Білорусія & 19255 & 4388 & 112 & 0,6 \\
\hline Україна & 13184 & 2097 & 327 & 2,5 \\
\hline
\end{tabular}

Мета роботи - вивчення та узагальнення досвіду фахівців 3 різних країн щодо актуальних питань захворювання COVID-19. 
Матеріали та методи дослідження. За допомогою історичного, бібліосемантичного і порівняльного аналізу та системного підходу проведено узагальнення даних літератури стосовно етіологічних, епідеміологічних, клінічних і діагностичних аспектів нової коронавірусної інфекції, структури і частоти ускладнень.

Результати дослідження та їх обговорення. У структурі госпіталізованих хворих 3 приводу ГРВІ коронавірусна інфекція становить в середньому 12\%. Про широку поширеність різних коронавірусів свідчать специфічні антитіла, які виявлені у $80 \%$ людей.

Коронавіруси мають глобальне поширення і сезонно-ендемічні характеристики. Вони цілий рік присутні в структурі ГРВI, i, як правило, викликають ураження верхніх дихальних шляхів легкого та середнього ступеня тяжкості. Як правило, захворюваність досягає піку взимку і навесні, причому описані випадки і на початку літа. В той же час в Ухані, на тлі підвищення захворюваності на початку 2020 року на коронавірусну інфекцію, досягла піку і активність сезонного грипу. Це значно утруднило діагностику захворювань, тим більше у випадках коінфекції. В подальшому при виявленні коінфекції, були надані рекомендації стосовно розширення методів обстеження хворих на РНК і антигени вірусів грипу.

Шляхами передачі інфекції при COVID-19 є: повітряно-краплинний (при кашлі, чханні, розмові, контакті на близькій відстані), повітряно-пиловий і контактний. Факторами передачі виступають: повітря, харчові продукти та предмети побуту, які контаміновані 2019-nCoV.

Основними зареєстрованими механізмами передачі є сімейні спалахи, що виникають у результаті контакту з інфікованою особою, набуті в результаті контакту у закладах охорони здоров'я між пацієнтами, між пацієнтами і працівниками охорони здоров'я і навпаки. Крім того, описані спалахи, коли було задіяно кілька видів передачі.

Передача COVID-19 від людини до людини відбувається головним чином між членами сім'ї, включаючи родичів і друзів, які тісно спілкувалися з пацієнтами або носіями. На відміну від COVID-19, передача SARS-CoV i MERS-CoV відбувалась в основному через внутрішньолікарняну передачу. Найбільш поширеним шляхом зараження при MERS-CoV було інфікування за рахунок захворілих медичних працівників (зареєстровані в 33-42\% випадків ГРВI) та передачі між пацієнтами (62-79\%). На даний час залишаються недостатньо зрозумілими джерело і механізм передачі при COVID-19.

Були встановлені біологічні рідини, що можуть поширювати інфекцію. Так PHK SARSCoV-2 була виявлена в слині, зразках із верхніх і нижніх дихальних шляхів, у рідині бронхоальвеолярного лаважу, в зразках крові, стулу і сперми.

Встановлено, що віруси можуть передаватися від людини людині через прямий або непрямий контакт, через великі або маленькі краплі, прямо або побічно через слину. Тривалість виявлення PHК SARS-CoV-2 в зразках верхніх і нижніх дихальних шляхів і в позалегеневих зразках ще не відома, але може становити кілька тижнів або довше, що спостерігалося у випадках інфекції MERS-CoV aбo SARS-CoV. У той час як життєздатний SARS$\mathrm{CoV}$ був виділений зі зразків дихальних шляхів, крові, сечі і стулу, для порівняння, при MERS$\mathrm{CoV}$ вірус був виділений лише зі зразків дихальних шляхів. Поки недостатньо відомо, чи можуть інші рідини організму інфікованої людини, включаючи блювотні маси, грудне молоко або сперму, містити життєздатні віруси SARS-CoV-2. Встановлено, що вірус може бути в повітрі завдяки аерозолю, який утворюєься під час медичних процедур. На даний час ще недостатньо відомі початок і тривалість виділення вірусу і період заразності для COVID-19. Вважають, що цілком можливо, що PHК SARS-CoV-2 може бути виявлена у верхніх або нижніх дихальних шляхах протягом декількох тижнів після початку захворювання, подібно інфекції MERS-CoV i SARS-CoV. Однак виявлення вірусної РНК не обов'язково означає наявність активного вірусу.

Ураження шлунково-кишкового тракту інфекцією SARS-CoV-2 і виділення вірусної РНК із зразків фекалій пацієнтів підтверджують важливість вивчення фекально-орального шляху при передачі 2019-nCoV. Описані випадки діареї у молодих людей з однієї родини, в якій був випадок SARS-CoV-2, що передбачає можливість ураження шлунково-кишкового тракту при даній інфекції і фекально-орального механізму передачі. В деяких випадках виявлений життєздатний вірус у фекаліях. Передбачається, що подальша передача від людини до людини 
відбувається фекально-оральним шляхом, через контаміновані руки, їжу і воду, однак до даного шляху передачі $\epsilon$ різні відношення і він може бути важливим при певних обставинах.

Дані мета-аналізу 60 досліджень, що включали 4243 пацієнтів з COVID-19, свідчать про виявлення вірусної РНК в зразках стулу пацієнтів навіть після негативації респіраторних аналізів. Згідно Cheung KS et al., 2020, розповсюдженість шлунково-кишкових симптомів при коронавірусній хворобі склала 17,6\% (95\% ДI, 12,3-24,5\%). Загальна розповсюдженість позитивних по РНК зразків стулу, склала 48,1\% (95\% ДI, 38,3-57,9\%); із цих зразків 70,3\% склали ті, що були зібрані після зникнення вірусу з респіраторних зразків (95\% ДI, 49,6-85,1\%). Тому рекомендовано медичним працівникам проявляти обережність при зборі проб фекалій чи виконанні ендоскопічних процедур у пацієнтів з COVID-19, навіть під час одужання пацієнта [29]. В той же час згідно зі спільним звітом В003-Китай, фекально-оральний шлях передачі не став важливим фактором поширення інфекції.

Контактно-побутовий шлях реалізується через такі фактори передачі: воду, харчові продукти і предмети (дверні ручки, екрани смартфонів), контаміновані збудником. Доведений ризик перенесення вірусу з рук на слизові оболонки очей, носової та ротової порожнини.

Стосовно інших коронавірусів, у дослідженні «випадок-контроль», в якому порівнювались пацієнти з MERS у Саудівській Аравії, був виявлений прямий контакт 3 інфікованими за 2 тижні до початку захворювання, пов'язаного з хворобою MERS-CoV. Bci спалахи в інших країнах були пов'язані з поїздками на Близький Схід або в Північну Африку.

Sean Wei Xiang Ong et al., 2020, провели обстеження за допомогою ПЛР змивів 3 поверхонь у квартирі. При цьому 87\% позитивних результатів отримано з різних поверхонь - 3 ліжок, вимикачів, тумбочок, кондиціонерів, вентиляційних шахт та 60\% із місць загального використання - з унітазу, раковини, дверних ручок. Зразки з поверхонь та повітря у прихожій $\mathrm{i}$ в коридорі були негативними, один мазок з передньої поверхні взуття був позитивним. Значне забруднення навколишнього середовища пацієнтами з SARS-CoV-2 через респіраторні краплі та виділення з фекалій вказує на те, що навколишнє середовище $є$ потенційним засобом передачі інфекції, і підтверджує необхідність суворого дотримання гігієни оточуючого середовища і гігієни рук [5].

За результатами досліджень Neeltje van Doremalen et al., 2020, встановлено, що збудник SARS-CoV-2 залишився активним у аерозолі під час експерименту (3 години), але зі зменшенням титру з $10^{3,5}$ до $10^{2,7} \mathrm{TCID}_{50}$ на літр повітря. Це зниження було аналогічно тому, яке спостерігалося при SARS-CoV-1, 3 104,3 до 103,5 TCID $_{50}$ на мілілітр. SARS-CoV-2 був більш стабільним на пластиці і нержавіючій сталі, ніж на міді і картоні. Життєздатний вірус був виявлений через 72 години після нанесення на ці поверхні, хоча титр вірусу був значно знижений (з $10^{3,7}$ до $10^{0,6}$ TCID 50 на мілілітр середовища після 72 годин на пластиці і від $10^{3,7}$ до 100,6 TCID $_{50}$ на мілілітр після 48 годин на нержавіючій сталі). Кінетика стабільності SARS-CoV-1 була аналогічною (від $10^{3,4}$ до $10^{0,7} \mathrm{TCID}_{50}$ на мілілітр через 72 години на пластиці і від $10^{3,6}$ до 100,6 TCID $_{50}$ на мілілітр через 48 годин на нержавіючій сталі). На міді не було виміряно життєздатного SARS-CoV-2 через 4 години, a SARS-CoV-1 через 8 годин. На картоні життєздатний SARS-CoV-2 не виявлявся через 24 години, а SARS-CoV-1 через 8 годин. Періоди напіврозпаду SARS-CoV-2 і SARS-CoV-1 були однаковими в аерозолях, в середньому приблизно через 1,1 до 1,2 години. Періоди напіврозпаду обох вірусів також були схожі на міді. На картоні період напіврозпаду SARS-CoV-2 був більшим, ніж у SARS-CoV-1. Найдовша життєздатність обох вірусів була на нержавіючій сталі і пластмасі. Розрахунковий середній період напіврозпаду SARS-CoV-2 становив приблизно 5,6 годин для нержавіючої сталі і 6,8 годин для пластику. Дослідники виявили, що стабільність SARS-CoV-2 була схожою зі стабільністю SARS-CoV-1 в експериментальних умовах [6].

Автори зробили висновок, що відмінності в епідеміологічних характеристиках цих вірусів, ймовірно, обумовлені іншими факторами, включаючи високе вірусне навантаження у верхніх дихальних шляхах і можливість людей, інфікованих SARS-CoV-2, виділяти і передавати вірус. Результати досліджень показали, що передача SARS-CoV-2 у вигляді аерозолів і фомітів $\epsilon$ правдоподібною, оскільки вірус може залишатися життєздатним і активним в аерозолях і на 
поверхнях протягом декількох годин. Ці результати повторюють дані досліджень з SARS-CoV-1, в яких такі форми передачі були пов'язані з внутрішньолікарняним поширенням [6].

Дослідження Duan SM et al., 2003, показали, що коронавірус SARS може виживати в сироватці, розведеній мокроті (1:20) і калі протягом щонайменше 96 годин, в сечі протягом щонайменше 72 годин. При вивченні зразків з поверхонь восьми різних матеріалів і з води встановлено зниження активності через 72-96-годин. Віруси залишалися стабільними при $4^{\circ} \mathrm{C}$, при кімнатній температурі $\left(20^{\circ} \mathrm{C}\right)$ і при $37^{\circ} \mathrm{C}$ протягом не менше 2 год. без помітної зміни активності в клітинах, але були інактивовані після 90, 60 і 30 хвилин експозиції при температурі $56^{\circ} \mathrm{C}, 67^{\circ} \mathrm{C}$ i $75^{\circ} \mathrm{C}$, відповідно. Опромінення ультрафіолетом вірусу протягом 60 хв на живильному середовищі сприяло зниженню його активності до невизначуваного рівня [7].

За даними G. Kampf et al., 2020, людські коронавіруси можуть залишатися активними на неживих поверхнях при кімнатній температурі до 9 днів. При температурі $30^{\circ} \mathrm{C}$ i вище тривалість активності та стійкості коротша. Показано, що ветеринарні коронавіруси зберігаються ще довше - протягом 28 днів. Тому забруднення поверхонь з частими дотиками в медичних установах $\epsilon$ потенційним джерелом передачі вірусу. Дані про переносимість коронавірусів із забруднених поверхонь на руки не виявлені. Однак при вірусі грипу А контакт протягом 5 с може передати 31,6\% вірусного навантаження на руки. Ефективність перенесення була нижчою $(1,5 \%)$ у вірусу парагрипу з 3 і 5-секундним контактом між поверхнею і руками. В обсерваційному дослідженні було встановлено, що студенти торкаються до свого обличчя руками в середньому 23 рази на годину, контактують в основному зі шкірою (56\%), ротом (36\%), носом (31\%) і очима (31\%). На даний час вірусне навантаження коронавірусів на неживих поверхнях під час спалаху невідоме [8].

Також поки недостатньо даних щодо ролі безсимптомної форми при передачі інфекції. Біля 1-3\% людей є безсимптомними носіями. За даними літератури носії збудника, коли у них немає клінічніх проявів, стають причиною зараження в $10 \%$ випадків. За попередніми даними, при коронавірусній інфекції хворі можуть передавати вірус до появи симптомів (у 10\% випадків).

Встановлений високий ризик передачі SARS-CoV-2 у родинах. Є повідомлення про випадки захворювань всередині сім'ї, коли у більшості родичів могли бути будь-які симптоми і зміни на рентгенівських знімках, а у решти відсутні. Також у деяких членів сім'ї були відсутні будь-які симптоми і зміни на рентгенівських знімках, але дослідження слизу з верхніх дихальних шляхів показали наявність вірусу. У всіх пацієнтів результати RT-PCR були позитивними на COVID-19. У деяких розвинулася важка пневмонія; у інших були помірно виражені прояви. Всі пацієнти 3 симптомами мали зміни в легенях за даними КТ у вигляді багатофокальних вогнищ у вигляді «матового скла». У всіх пацієнтів з симптомами спостерігалося підвищення рівня СРБ і зниження кількості лімфоцитів [9]. Сімейні спалахи описують i Hai Nguyen et al., 2020, які зробили висновки, що можливі безсимптомні випадки інфекції і випадки передачі інфекції при її безсимптомному перебігу. Описаний випадок змін в легенях у вигляді «матового скла» $\mathrm{i}$ виявлення PHК SARS-CoV-2 в зразку мокротиння у дитини без клінічних симптомів [10]. $€$ повідомлення про випадок інфекції COVID-19 в Німеччині, коли передача вірусу відбулась при контакті з безсимптомними пацієнтами.

На даний час встановлений факт статевого шляху передачі коронавірусу, у зв'язку з тим, що вірус може знаходитись у спермі.

Великий ризик передачі при COVID-19 медичним працівникам. Під час спалаху атипової пневмонії у 2002 році $21 \%$ постраждалих були працівниками охорони здоров'я. Встановлено зв'язок інфекції, викликаної 2019-nCoV, з наданням медичної допомоги (серед медичного персоналу, які контактували з хворими). Факт реалізації артифіціального механізму передачі SARS-CoV-2 встановлений у КНР. Серед медичних працівників, які надавали допомогу хворим 3 COVID-19, було зареєстровано 3387 випадків інфікування, у $22(0,6 \%)$ розвинулись летальні наслідки. Більше 90\% інфікованих працівників були з провінції Хубей.

За даними Jiancong Wang зі співавт., 2020, причиною цього були: 1) неадекватний особистий захист медичних працівників на початку епідемії, завдяки тому, що вони погано розуміли про загрозу та особливості даної інфекції; 2) тривалий контакт з інфікованими 
пацієнтами безпосередньо збільшував ризик зараження для працівників охорони здоров'я; 3) велике навантаження на медичний персонал при наданні медичної допомоги та відсутність відпочинку збільшували ймовірність зараження; 4) брак засобів індивідуального захисту (3І3); 5) медичні працівники, які працювали у первинній ланці (крім лікарів-інфекціоністів), пройшли неадекватну підготовку щодо особливо-небезпечних інфекцій, їх профілактики, організації роботи; 6) після початку епідемії у працівників охорони здоров'я не було достатньо часу для систематичного навчання і практики; 7) були відсутні алгоритми дій по ситуаціях, керівництво з діагностики, лікування, профілактики, механізм моніторингу [11].

Слід пам'ятати, що працівники закладів охорони здоров'я особливо схильні до ризику зараження під час нинішньої епідемії. Тому медичні працівники, які проводять огляд, лікують, доглядають повинні дотримуватись відповідних правил. Особливо слід звертати увагу на запобігання інфекції при проведенні процедур, при яких генерується аерозоль.

Також і під час попередніх епідемій у медичних закладах передача SARS-CoV i MERS-CoV від людини людині відбувалась головним чином через внутрішньолікарняну передачу. Від 43,5 до 100\% пацієнтів з MERS в окремих спалахах були пов'язані з лікарнями. Медичні працівники становили $22 \%$ серед зареєстрованих випадків у Китаї і $>40 \%$ в Канаді. В той же час передача захворювання між членами сім'ї сталася тільки в 13-21\% випадків MERS і в 22-39\% випадків SARS.

Дослідження у Республіці Корея показало, що у випадках збільшення тривалості перебування хворих у лікарні без ізоляції, особливо з температурою тіла $\geq 38,5^{\circ} \mathrm{C}$, при ураженні легень $\geq 3$ зон, частіше відбувалось інфікування як медичного персоналу, так і інших хворих. В іншому корейському дослідженні встановлено, що рідко відбувалась передача MERS інфекції від безсимптомного пацієнта. На відміну від SARS-CoV-2, SARS-CoV i MERS-CoV, пряма передача від людини до людини не була зареєстрована для інших коронавірусних інфекцій.

У дослідженні, яке було проведено раніше, встановлено виділення збудника MERS-CoV у осіб без симптомів. У іншому звіті було виявлено, що з $30 \%$ випадків з безсимптомними формами вірус був виявлений в зразках із верхніх дихальних шляхів на 12-й день у 76\% випадків. Даний випадок демонструє, що деякі люди здатні виділяти коронавіруси протягом тривалих періодів часу і без явних симптомів. У цю групу осіб можуть входити медичні працівники, які здатні передавати вірус пацієнтам при відповідних умовах з наступною появою нових інфекцій. Неможливість своєчасного виявлення випадків COVID-19 може паралізувати роботу медичного закладу, зруйнувати систему громадської охорони здоров'я і призвести до величезних економічних втрат. У зв'язку з цим, крім проведення дезінфекційних заходів у закладах охорони здоров'я, необхідно проводити обстеження медичного персоналу для обмеження внутрішньолікарняного поширення та уникнення внутрішньолікарняних спалахів. Ці безсимптомні і тривалі виділення збудника MERS-CoV можуть призвести до появи нових інфекцій без чітких ланцюгів передачі у пацієнтів, які перебували в лікарні протягом >1 інкубаційного періоду [12].

Безсимптомний перебіг і безсимптомне виділення вірусів представляє серйозну проблему для контроля за інфекцією. Пацієнтів з легкими і неспецифічними симптомами важко ідентифікувати та ізолювати, особливо на ранніх стадіях спалаху. Важливо, що відсутність лихоманки при SARS-CoV-2 інфекції $(12,1 \%)$ зустрічається частіше, ніж при SARS$\operatorname{CoV}(1 \%)$ i MERS-CoV (2\%), та має потенційні загрози. Зокрема, згідно деяких досліджень, збільшення кількості безсимптомних форм при MERS-CoV з 0\% до 28,6\%, негативно вплинуло на рівень смертності на початковому етапі, бо на ранніх стадіях будь-якого спалаху спочатку виявляються важкі випадки, в той час як безсимптомні форми також несуть загрозу зараження.

Частка безсимптомних серед зареєстрованих підтверджених випадків MERS-CoV у дітей була вищою (41,9-81,8\%). В цілому, частота виявлення інфекції MERS серед безсимптомних контактів становила 1-3,9\% в дослідженнях, включених в цей огляд [13].

Встановлено, що багато вірусних інфекцій пов'язані з безсимптомними, субклінічними або дуже легкими формами. За даними CDC, у разі поліомієліту 95\% інфікованих залишаються безсимптомними, але вони здатні поширювати вірус. В одному дослідженні безсимптомна риновірусна інфекція зустрічалася в чотири рази частіше, ніж симптоматична. Інше 
дослідження показало, що кількість безсимптомних носіїв вірусу грипу становить 5,2-35,5\%. Безсимптомні ГРВI, засновані на серологічних дослідженнях, склали $13 \%$ порівняно з важким $(82 \%)$ і легким (4\%) перебігом.

Таблиця 2

Частка безсимптомних MERS-CoV серед протестованих осіб на основі ПЛР зі зворотною транскриптазою

(згідно з Jaffar A.Al-Tawfiq, Philippe Gautret, 2019)

\begin{tabular}{|l|c|}
\hline \multicolumn{1}{|c|}{ Категорія хворих } & Відсоток безсимптомних випадків (\%) \\
\hline $\begin{array}{l}\text { Лабораторно підтверджені та ймовірні випадки MERS-CoV з } \\
\text { країн }\end{array}$ & $18 / 144$ (12,5\%) \\
\hline Контактні з числа медпрацівників & $4 / 520(1 \%)$ \\
\hline Контактні у Південній Кореї & $3 / 186(1,6 \%)$ \\
\hline Спалаху Джидді & $64 / 255(25 \%)$ \\
\hline Педіатричні пацієнти & $9 / 11(82 \%)$ \\
\hline Педіатричні пацієнти & $13 / 31(42 \%)$ \\
\hline Госпіталізовані & $3 / 7(42,8 \%)$ \\
\hline
\end{tabular}

3 моменту появи SARS-COV-2 в Ухані у грудні 2019 року, кількість випадків захворювань у країнах світу значно зросла, причому часто пов'язана з передачею від безсимптомних інфікованих. Інфіковані без симптомів, які знаходяться в інкубаційному періоді можуть поширювати вірус. Встановлено, що живі віруси присутні в слині заражених людей. $€$ повідомлення про передачу збудника від безсимптомного іншому пацієнтові. Вірусне навантаження у безсимптомних носіїв $\epsilon$ відносно низьким.

Затримка від появи симптомів до ізоляції зіграла важливу роль в досягненні контролю над спалахами. Встановлено, що при зростанні відсотку відстеження контактів зменшується ризик розповсюдження хвороби і навпаки. Якщо передача не відбулася до появи симптомів, то ймовірність досягнення контролю над розповсюдженням була вищою.

У сценаріях, в яких відбувалось зростання кількості безсимптомних випадків, ймовірність контролю ситуації завдяки ізоляції та відстеженню контактів зменшувалася. Необхідно щонайменше простежити й ізолювати $80 \%$ контактів з інфікованими, щоб забезпечити можливість контролю 90\% або більше. Це вказує на те, що для контролю над спалахами необхідне високоефективне відстеження контактів. В сценаріях, в яких затримка від появи випадків захворювання до їх ізоляції була тривалою (як на початку епідемії в Ухані), відстеження контактів становило до 80\%, ймовірність стримування спалаху була меншою за 40\%. Збільшення відсотка передсимптомної передачі знижує ймовірність контролю над спалахами.

Показники швидкості передачі від людини із симптоматичною інфекцією залежать від місця інфікування та стану контролю за інфекцією. Відповідно до звіту В003-Китай, частота вторинних COVID-19 випадків становила від 1 до 5\% серед десятків тисяч щільних контактів, підтверджених у Китаї. У США частота вторинних випадків становила 0,45\% серед 445 щільних контактів із десятьма підтвердженими випадками. За даними Yang Liu et al., 2020, відсоток вторинної передачі від хворих з SARS-CoV-2 при щільному контакті з хворим дорівнює близько $35 \%$ [14].

На даний час доступна інформація стосовно можливості тривалого виділення вірусу (тижні, навіть місяці) в осіб, які перехворіли на COVID-19 та не мають клінічних проявів. Проводяться дослідження стосовно вирішення питання, наскільки ці віруси активні та можуть викликати захворювання. Потребує уточнення питання щодо активного масового тестування громадян України, тим більше, що навіть у хворих з клінікою COVID-19, швидкі тести, включаючи ПЛР, можуть бути помилково негативні! 

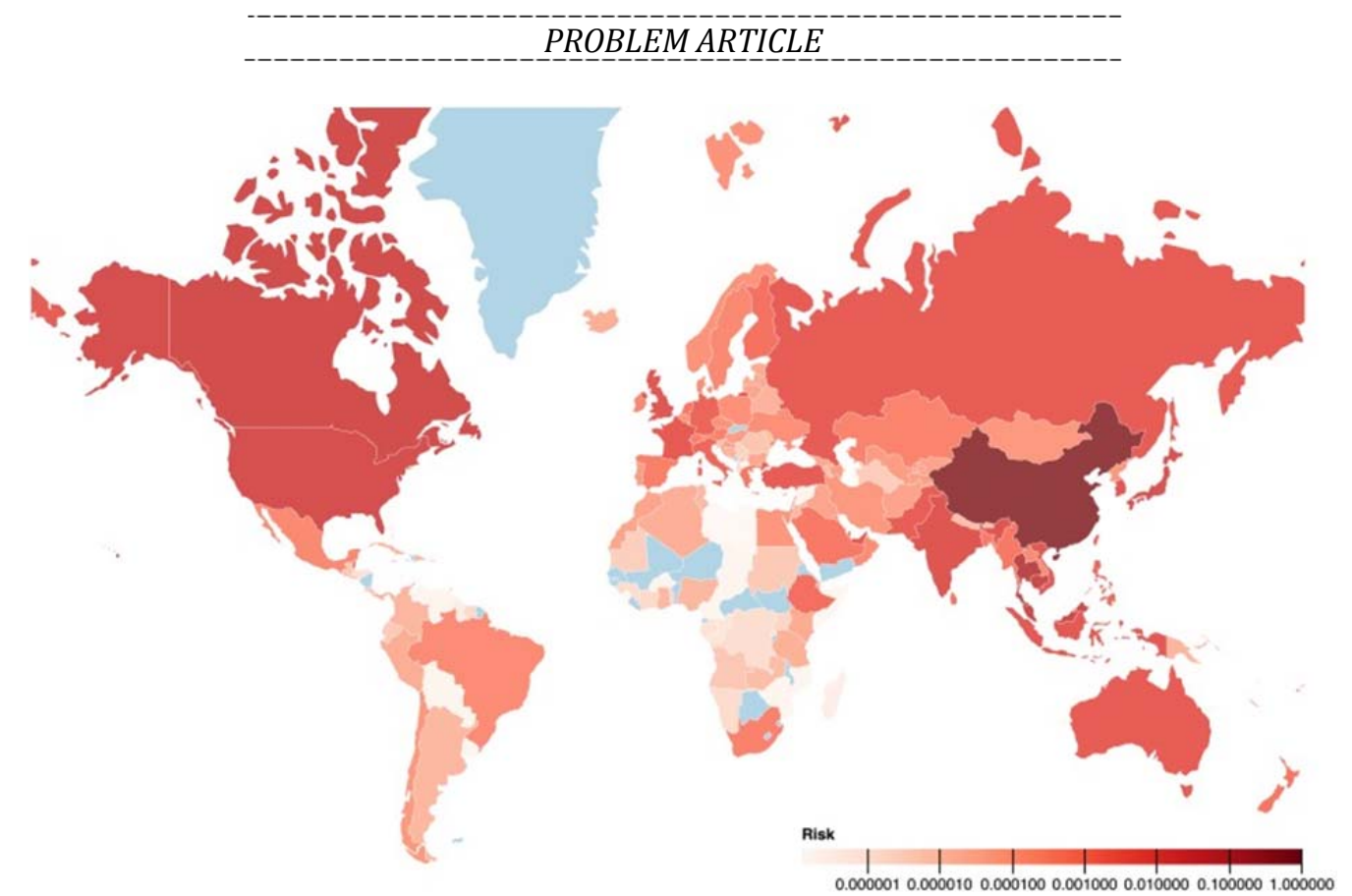

Рисунок 1. Карта 3 індексом ризику передачі SARS-COV-2 в країнах світу або на територіях. Більш темний колір вказує на більш високий ризик, а світло-синій колір вказує на відсутність даних.

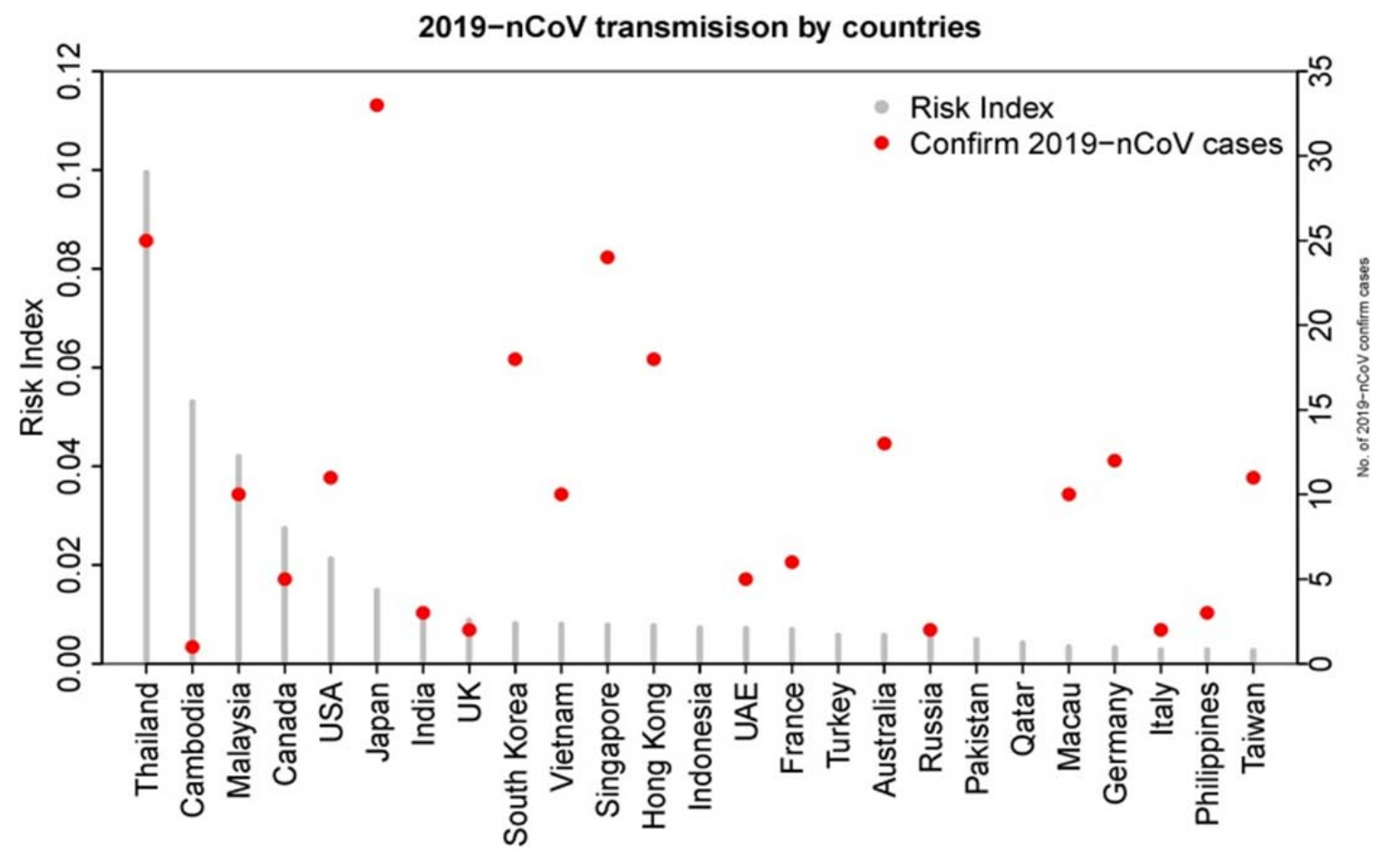

Рисунок 2. Діаграма відносного ризику передачі коронавірусу (SARS-COV-2) у країнах світу за межами Китаю

Слід окремо актуалізувати фактори, які впливають на розповсюдження вірусу: кількість інфікованих, яких імовірно може заразити хворий; серійний інтервал - час між інфікуванням однієї людини й тим моментом, коли інфікується інша. Серійний інтервал для SARS-Co-2 складає приблизно 4 дні. Передбачається, що репродуктивне число (число вторинних випадків зараження, викликаних однією інфікованою людиною) для вірусу COVID-19 становить в середньому 2,2 (від 1,4 до 6,5), що вище, ніж для сезонного грипу (середне число 1,28 (від 1,19 до 1,37), для пандемічного грипу H1N1 2009 - 1,3), для SARS-CoV біля 2, для кору звичайно 1218. Це приводить до подвоєння часу розвитку епідемії до 6,4 доби (B003; Mary A Lake, 2020) [15]. Грунтуючись на даних спостережень за епідемією коронавірусу на материковому Китаї в період з 10 по 24 січня 2020 р. середній показник репродуктивного числа склав від 2,24

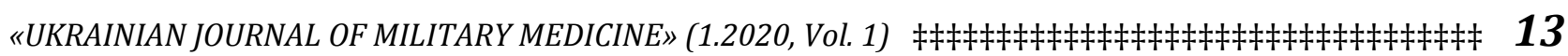


(інтервал від 1,96 до 2,55) до 3,58 (від 2,89 до 4,39), час подвоєння епідемії - до 8 діб. За іншими дослідженнями, проведеними 331 грудня 2019 р. по 28 січня 2020 р. для COVID-19, репродуктивне число становить 2,68, час подвоєння епідемії - 6,4 дня. Середній інкубаційний період для COVID-19 становить 6,4 дня (від 2,1 дня до 11,1 дня), з потенційною безсимптомною передачею [16].

Далі представлена карта з індексом ризику передачі SARS-COV-2 в країнах світу або на окремих територіях. Ризик передачі SARS-COV-2 з Китаю 31 січня 2020 р. був найвищим для сусідніх країн Азії (Таїланд, Камбоджа, Малайзія), за якими слідують країни Європи (Великобританія, Франція, Росія і Німеччина), Океанії (Австралія і Нова Зеландія) і Північної Америки (США та Канада). Ситуація є динамічною і, можливо, змінилася в зв'язку із закриттям рейсів і кордонів. Більш високий коефіцієнт кореляції з мандрівниками і даними по виявленню випадків вказують на те, що COVID-19 залишатиметься значною загрозою при повітряному переміщенні людей [17].

Розподіл хворих за віковими групами у різних країнах представлений на рис. 3-9 [18, 19]. Згідно діаграми, наведеної на рис. 3, близько половини і більше хворих були у віці молодше 60 років.

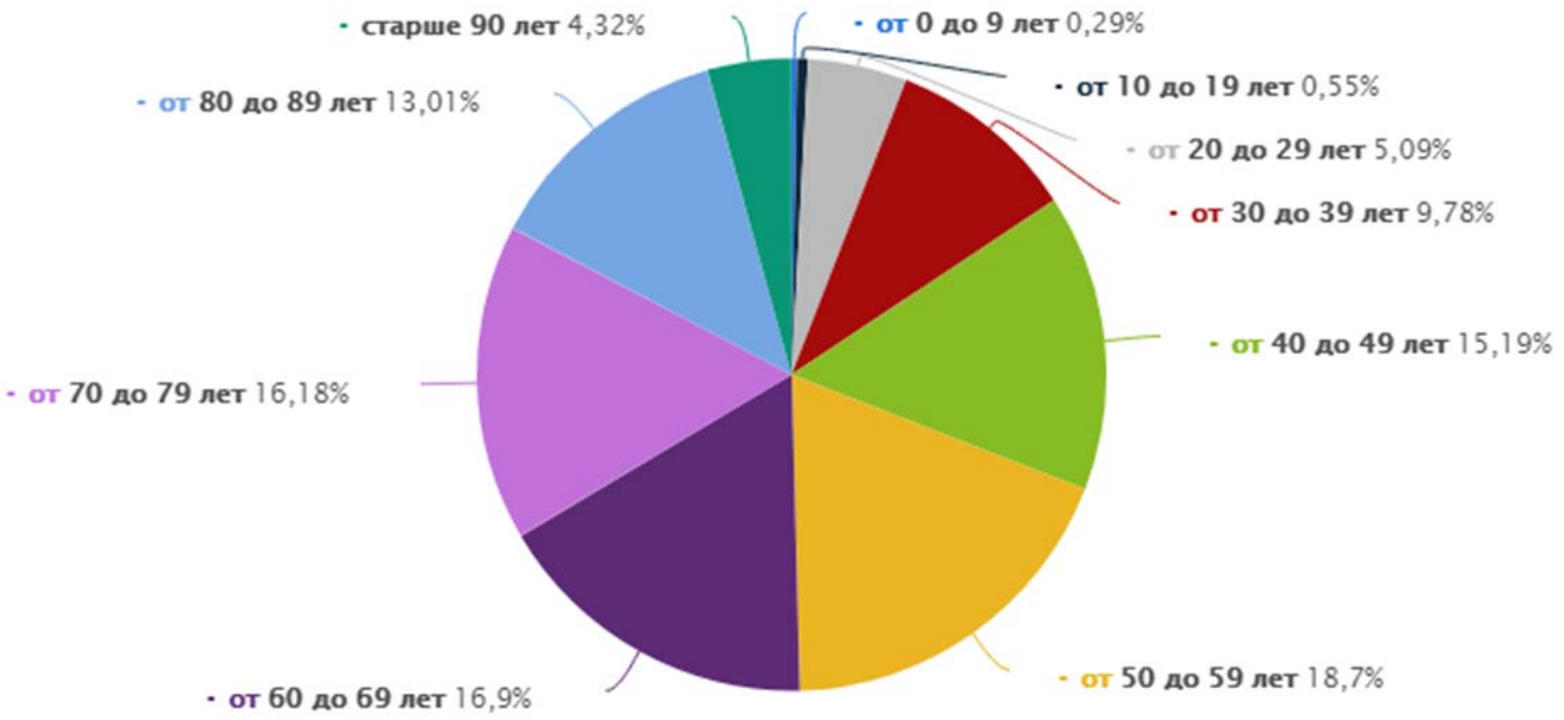

Рисунок 3. Розподіл хворих із COVID-19 в Іспанії станом на 8 квітня 2020 р. за віковими групами

Було висловлено припущення, що найбільш схильними до захворювання можуть бути люди з пригніченою імунною системою - літні та хворі з нирковою і печінковою дисфункцією.

Серед хворих більшість (59\%) становлять чоловіки старшого віку. Раніше також було встановлено, що MERS-CoV та SARS-CoV інфікують частіше чоловіків, ніж жінок, де серед пацієнтів жінки склали 41,9-45,7\%. За даними Wei-jie Guan et al., 2020, відсоток жінок був 41,9\% [20].

За даними літератури більшість підтверджених випадків захворювання були легкі та середньоважкі (80-84,3\%), важких форм налічувалось 13-16\% і близько 5\% вкрай важких форм. Відомо, що у більшості інфікованих, особливо у молодому віці, захворювання має більш легкий перебіг, в порівнянні з особами старшого віку. 


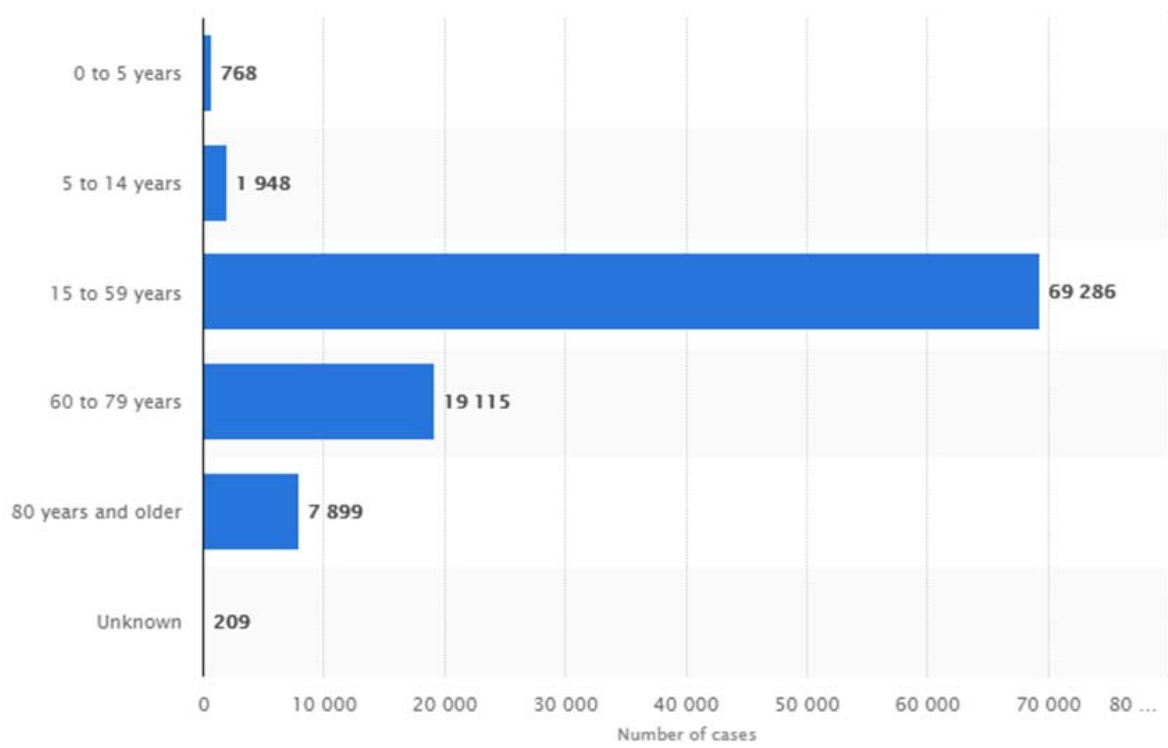

Рисунок 4. Розподіл хворих з COVID-19 за віковими групами у Німеччині у 2020 р.

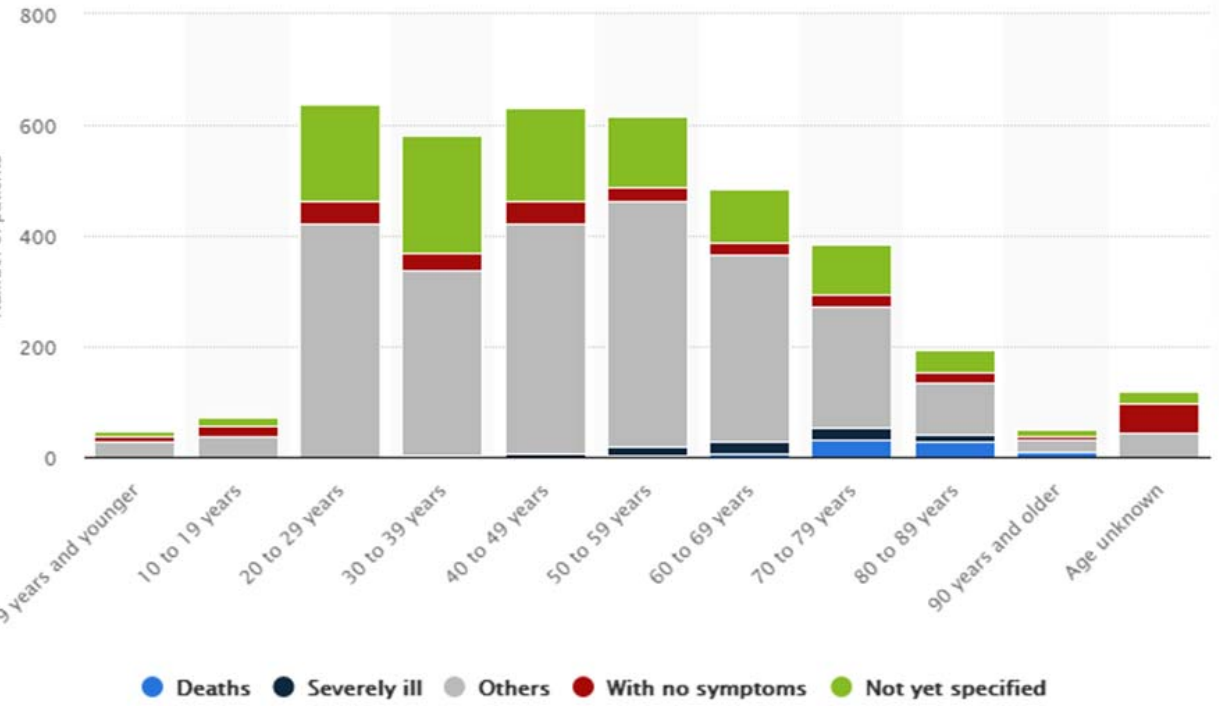

Рисунок 5. Розподіл хворих з COVID-19 за віковими групами та категоріями в Японії станом на 6 квітня 2020 р.

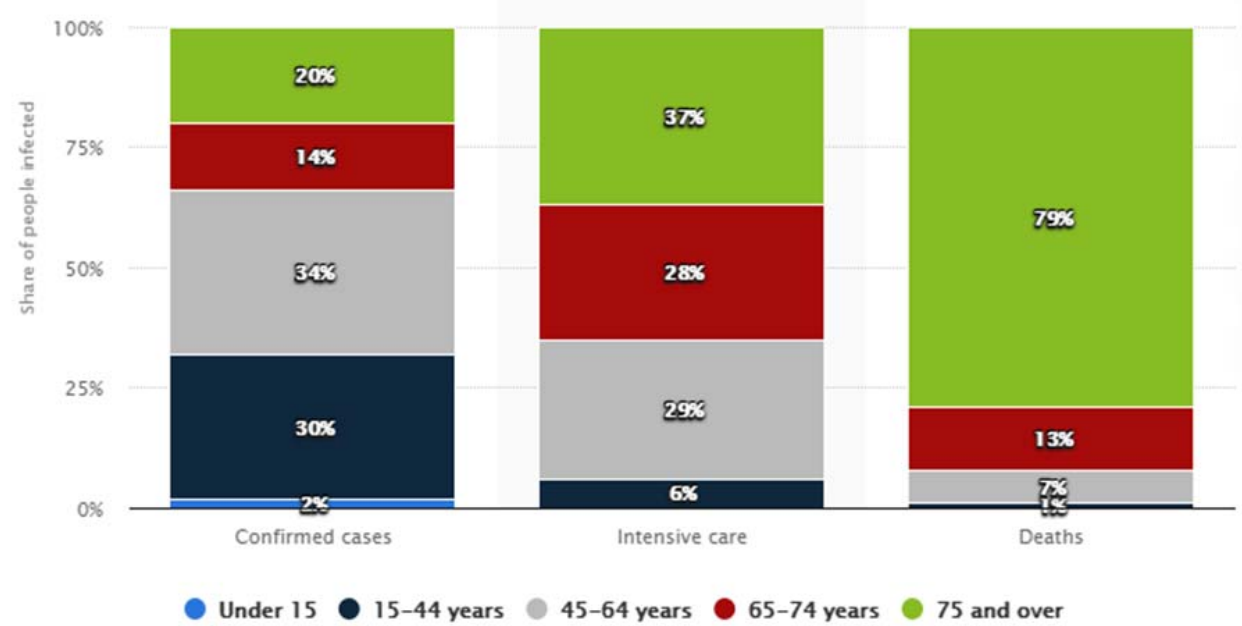

Рисунок 6. Розподіл хворих з COVID-19 за віковими групами та категоріями у Франції станом на 15 березня 2020 p. 


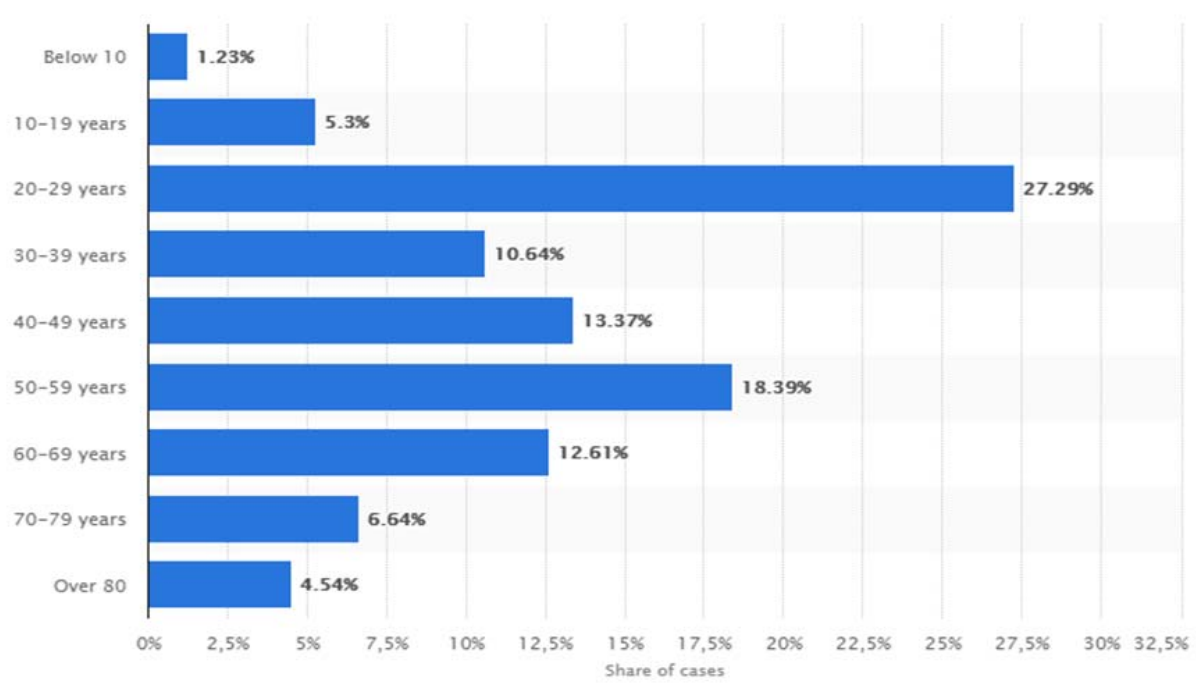

Рисунок 7. Розподіл хворих з COVID-19 за віковими групами у Південній Кореї станом на 9 квітня 2020 p.

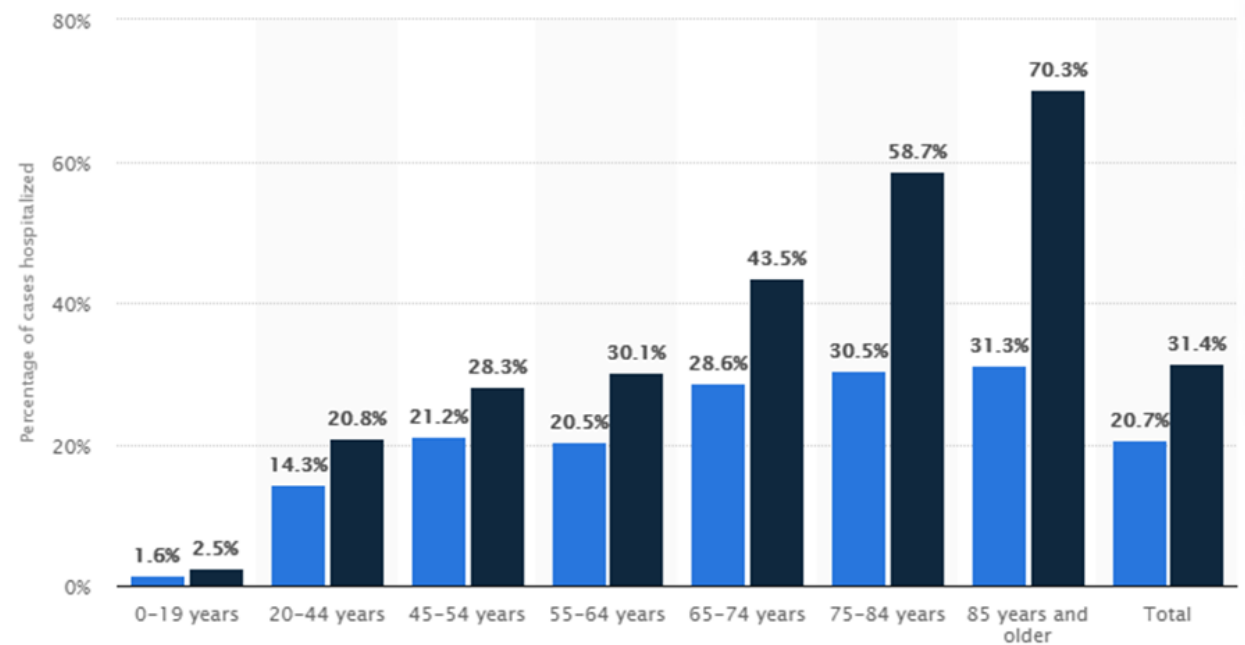

Рисунок 8. Розподіл госпіталізованих хворих з COVID-19 за віковими групами у США з 12 лютого по 16 березня 2020 p.

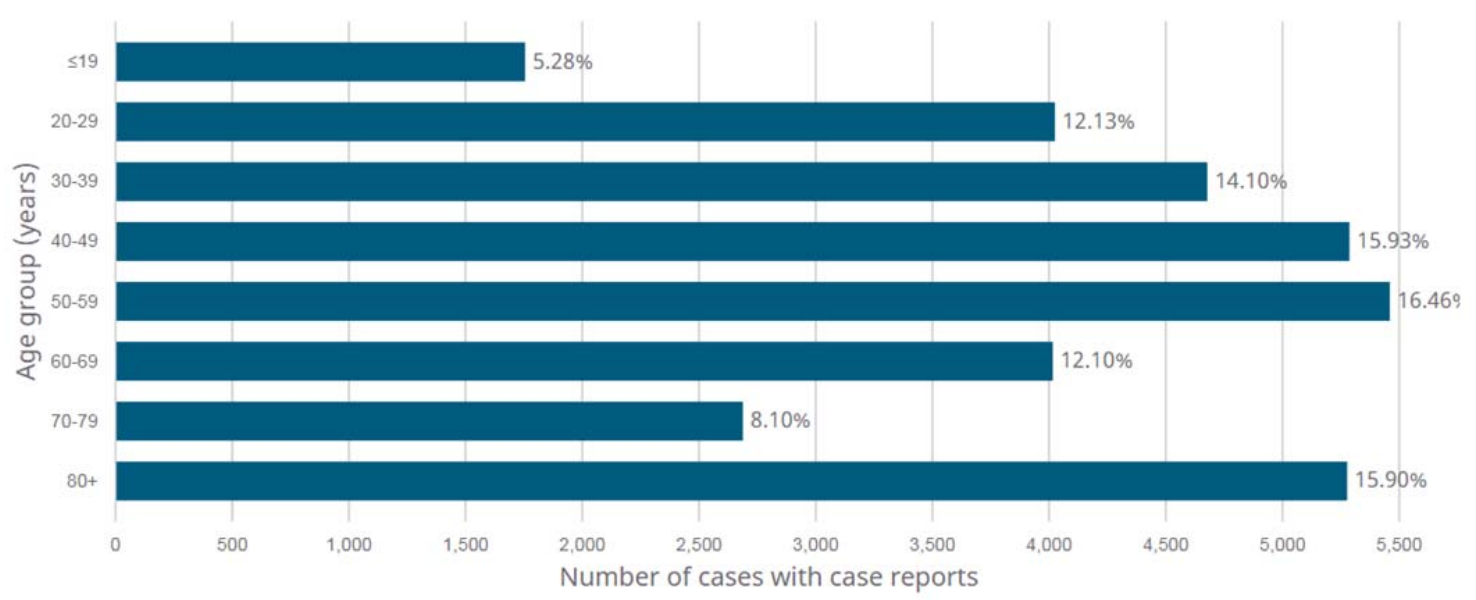

Рисунок 9. Розподіл хворих з COVID-19 за віковими групами у Канаді станом на 7 травня $2020 \mathrm{p}$. 
Пацієнти з важкою формою були старшими, ніж пацієнти з легшими формами. Супутні захворювання частіше зустрічалися серед пацієнтів із важкими формами, ніж у пацієнтів із більш легкими $(38,7 \%$ проти $21,0 \%)$.

На даний час відомо, що безсимптомний інкубаційний період для людей, інфікованих 2019-nCov, в середньому складає 5,0 днів [ДІ від 4,1 до 7,0 днів], мінімальний та максимальний 1-14 днів, в той же час $є$ інформація і про випадки захворювань навіть через 24 дні.

Клінічні ознаки захворювання неспецифічні. Інфекція у людей має широкий спектр клінічних проявів та ступінь їх вираженості, що значно ускладнює своєчасну діагностику. Хвороба може нагадувати захворювання, які спричиняють респіраторно-синцитіальна, парагрипозна або риновірусна та інші інфекції.

Згідно різних методичних рекомендацій, стандартів, протоколів клінічними варіантами та проявами 2019-nCoV інфекції є: гостра респіраторна вірусна інфекція легкого перебігу; пневмонія без дихальної недостатності; пневмонія з гострою дихальною недостатністю; гострий респіраторний дистрес-синдром (ГРДС); сепсис; септичний (інфекційно-токсичний) шок. Розрізняють легкі, середні і важкі форми 2019-nCoV інфекції. Терміни прогресування хвороби з початку появи симптомів (за Wei-jie Guan et al., 2020) наведені в табл. 3.

Встановлено, що серед перших симптомів захворювання можуть бути біль у м'язах (11\%), сплутаність свідомості (9\%), головний біль (8\%), кровохаркання (5\%), діарея (3\%), нудота, блювота, серцебиття. Дані симптоми в дебюті інфекції можуть спостерігатися навіть при відсутності підвищення температури тіла. За даними Chih-Cheng Lai et al., 2020, у 43,8\% пацієнтів на початку захворювання розвивалась лихоманка [21]. За іншими даними на початку хвороби реєструються: лихоманка у 77-98\% хворих, кашель - у 46-82\%, міалгія або втома - у 11-52\%, задишка - у 3-31\%. Також реєструються менш часті респіраторні симптоми - біль в горлі, головний біль, кашель з виділенням мокроти і / або кровохаркання. У деяких хворих на початку хвороби як на фоні респіраторних проявів так і без них, до розвитку лихоманки $\mathrm{i}$ ураження нижніх дихальних шляхів, на фоні температури або без неї могли турбувати нудота, зниження апетиту, діарея до 4-6 разів на добу, судоми, запаморочення, і вже тільки на 3-4 добу підвищувалась температура, розвивались респіраторні прояви. У деяких пацієнтів були шлунково-кишкові симптоми (діарея і нудота), лихоманка до розвитку ознак і симптомів ураження дихальних шляхів. Лихоманка у пацієнтів з COVID-19 може бути тривалою або переривчастою.

Часто повідомляється про наступні ознаки і симптоми у госпіталізованих пацієнтів 3 новою коронавірусною інфекцією, викликаною 2019-nCoV: лихоманка (у 77-88,7\% хворих 3 температурою тіла $\geq 37,5^{\circ} \mathrm{C}$ ), нездужання (у >90\%); сухий кашель або з невеликою кількістю харкотиння (у 67,8-80\%) хворих, у частини відходження харкотиння (у 33,7\%); задишка (у 18,7$55 \%)$, втома (у 38,1\%), відчуття закладеності в грудній клітці (у $>20 \%)$, утруднене дихання (у $55 \%)$, розлади дихання (у 15\%), біль у м'язах (у 27,7-44\%), біль у м'язах або суглобах (у 14,9\%), міалгії і стомлюваність (у 44\%). Найбільш важка задишка розвивалась до 6-8-го дня від моменту захворювання. Значно рідше реєструвались - помірний або навіть дуже сильний головний біль (у 7,2-13,1\%), ринорея - у 4-5\%, біль в горлі - у 5,1- 17,4\%, нудота або блювота (у 5,0\%) та діарея (у 3,8-6,1\%). У деяких хворих була діарея (у 3,8\%) і кон'юнктивіт. Таким чином, клінічні прояви COVID-19 не відрізняються від інших респіраторних інфекцій.

Крім наведених проявів у хворих може спостерігатись виникнення кон'юнктивіту, висипки різного характеру, що потребує проведення диференційної діагностики 3 алергією, ентеровірусною інфекцією, септичним ендокардитом, парвовірусною інфекцією, кором, вітряною віспою та ін. В той же час не слід забувати про можливість існування мікст-інфекції.

У пацієнтів з COVID-19 аналізи крові зазвичай показують лейкопенію і лімфопенію, більшість даних сканувань органів грудної клітини за допомогою КТ встановлюють непрозорість і зміни у вигляді «матового скла» з двобічним ураженням легень. В той же час такі ж зміни можуть виявлятися і при грипі А, і при інших респіраторних вірусних захврюваннях. Таким чином, захворювання на COVID-19 може бути недіагностованим через помилково негативні тести у зразках з верхніх дихальних шляхів або при ко-інфекції з іншими респіраторними вірусами. Тому при підозрі на захворювання на COVID-19 необхідне більш 
широке вірусне тестування, особливо у випадках, коли це може суттєво вплинути на наслідки лікування [22].

Для вірусу грипу притаманна сезонність взимку, подібно до COVID-19. Клінічні прояви у пацієнтів з вірусом грипу включають лихоманку, кашель, риніт, біль у горлі, головний біль, задишку, міалгію та рентгенологічні ознаки пневмонії, які аналогічні таким у пацієнтів 3 COVID-19. Типові прояви KT в грудній клітці для пневмонії, викликаної вірусом грипу, також подібні з такими для COVID-19, включаючи «матове скло», консолідацію та плевральний випіт.

У деяких пацієнтів захворювання швидко прогресує та розвиваються різноманітні ускладнення, з розвитком поліорганної недостатності [23]. Фактори ризику важкого перебігу хвороби ще не ясні, хоча літні пацієнти та пацієнти з хронічними захворюваннями можуть піддаватися більшому ризику важкого перебігу. За різними даними приблизно у половини пацієнтів, заражених 2019-nCoV, були хронічні супутні захворювання, переважно серцевосудинні та цереброваскулярні і цукровий діабет, що схоже на MERS-CoV [1]. Тому раннє виявлення та своєчасне лікування критичних випадків має вирішальне значення.

У неважких випадках спостерігались звичайні симптоми гострого респіраторного захворювання та ускладнення практично не розвивались. В той же час, при середньоважкій та важкій формах у хворих на коронавірусну хворобу COVID-19 розвивались наступні ускладнення: пневмонія, ГРДС, ураження серця (міокардит та ін.), аритмія, дисфункція печінки, гостре ураження нирок з розвитком гострої ниркової недостатності, сепсис, септичний шок, поліорганна недостатність, отит, синусит, бронхіт, периферійна полінейропатія, вторинна інфекція, бактеріємія, грибкова суперінфекція.

Терміни прогресування хвороби з початку появи симптомів

Таблиця 3

(Wei-jie Guan et al., 2020)

\begin{tabular}{|l|c|}
\hline \multicolumn{1}{|c|}{ Стан } & Доба \\
\hline Госпіталізація & $7(4-8)$ \\
\hline Задишка & $8(5-13)$ \\
\hline ГРДС & $9(8-14)$ \\
\hline Механічна вентиляція легень & $10,5(7-14)$ \\
\hline Переведення у ВРІт & 10,5 \\
\hline
\end{tabular}

Найбільш поширеним клінічним проявом нового варіанту коронавірусної інфекції $є$ двобічна пневмонія. Еволюція легеневого і системного запалення в перші два тижні може визначати прогресування або регресування і результат захворювання (смерть або виживання) [24].

Як вказує Tanu Singhal, 2020, у деяких пацієнтів до кінця першого тижня захворювання може прогресувати до пневмонії, дихальної недостатності і смерті [25]. За даними Chih-Cheng Lai et al., 2020, важка пневмонія розвинулась у 15,7\% хворих. Середній час від початку хвороби до госпіталізації при пневмонії становив 9 днів. У трохи більше половини пацієнтів задишка розвинулась в середньому через 8 днів від початку хвороби (від 5 до 13 днів). Гіпоксемія (зниження $\mathrm{SpO}_{2}$ менше 88\%) розвинулась більш ніж у 30\% пацієнтів [21]. ГРДС розвинувся у 34\% пацієнтів, у 17-29\% госпіталізованих пацієнтів. За даними Mary A Lake, 2020, Chaolin Huang et al., 2020 він розвинувся у $29 \%$ хворих.

Слід відмітити, що відмінною рисою важкого COVID-19 є коагулопатія: 71,4\% пацієнтів, які помирають від COVID-19, відповідають критеріям ISTH для дисемінованого внутрішньосудинного згортання (ДВЗ-синдром).

Серед пацієнтів з COVID-19, особливо тих, хто перебуває у важкому і критичному стані, існує чимало потенційних факторів ризику венозної і артеріальної тромбоемболії, включаючи інфекцію, дихальну недостатність, штучну вентиляцію легень, використання центрального венозного катетера, надмірне запалення, гіпоксію, внутрішньосудинну коагуляцію. Частота гострої легеневої емболії у пацієнтів з діагнозом COVID-19 в даний час невідома. F.A. Klok et al., 2020, проводили дослідження щодо частоти симптоматичної гострої емболії легеневої артерії, тромбозу глибоких вен, ішемічного інсульту, інфаркту міокарда, системної артеріальної 
емболії у всіх пацієнтів з COVID-19, що надійшли до відділень інтенсивної терапії двох голландських університетських лікарень. Сукупна частота даних ускладнень склала 31\%, 3 яких КТ-ангіографія і/або УЗД підтвердили венотромбоемболію у $27 \%$ i артеріальні тромботичні ускладнення у 3,7\% хворих. Гостра емболія легеневої артерії була найбільш частим тромботичним ускладненням. Збільшення протромбіновго часу або активованого часткового тромбопластинового часу (АЧТЧ) були незалежними предикторами тромботичних ускладнень. При поступленні до ВРІТ коагулопатія була виявлена у $38 \%$ [26].

Серед ускладнень відмічають і ураження підшлункової залози (спостерігається підвищення рівня амілази або ліпази в сироватці крові) у 17\% пацієнтів. Розвиток анемії спостерігали у $15 \%$ хворих [27].

Iнфекція SARS-Cov-2 також може викликати і системне запалення, приводячи до поліорганної дисфункції в групах високого ризику [24]. Шок на фоні захворювання розвивався у 4-8\% пацієнтів.

Ураження печінки розвивалось у 14-53\% пацієнтів. Частіше реєструвалось у пацієнтів із важким захворюванням.

Бактеріальні інфекції розвинулись у 6-10\% пацієнтів [15, 27]. Серед ускладнень також спостерігали розвиток гострого ураження нирок у 3-8\% пацієнтів.

У пацієнтів 3 важкою хворобою зазвичай виникають неврологічні ускладнення. Ускладнення включають гостре цереброваскулярне захворювання, інсульт, порушення свідомості, атаксію, судоми, невралгію, травмування скелетних м'язів та енцефалопатію, гостру некротичну енцефалопатію. У хворих ці ознаки/симптоми можуть розвиватись на фоні захворювання або після «одужання». У таких пацієнтів прогноз несприятливий. За даними досліджень Ling Mao et al., 2020, у хворих з коронавірусною хворобою неврологічні симптоми (гострі цереброваскулярні захворювання, порушення свідомості, ураження м'язів) спостерігали у 36,4\%, із вищою частотою у пацієнтів з важким перебігом $(45,5 \%)$. У 36,4\% хворих були прояви ураження центальної і периферичної нервової системи (у 24,8 і 8,9\% відповідно) та пошкодження скелетних м'язів (у 10,7\%) [28].

При COVID-19 інфекції розвиваються невідкладні стани з боку серцево-судинної системи. У осіб, в яких раніше були серцево-судиннні захворювання $\epsilon$ підвищений ризик розвитку важких захворювань і смерті. При даній інфекції розвиваються різноманітні серцево-судинні ускладнення: гострий інфаркт, міокардит, аритмії, гострий коронарний синдром, венозна тромбоемболія, кардіогенний шок, кардіоміопатія та серцева недостатність. Частота розвитку гострого ураження серця зареєстрована у 7-20\% хворих. $€$ повідомлення про виявлення кардіоміопатії у 33\% важкохворих. В той же час невідомо, чи є це прямим впливом коронавірусу, чи опосередкованим через ураження інших органів. $€$ повідомлення про міоперикардит із систолічною дисфункцією у пацієнта без ознак/симптомів пневмонії через 1 тиждень після зникнення симптомів верхніх дихальних шляхів, що підкреслює необхідність суворого моніторингу пацієнтів із серцево-судинними захворюваннями в анамнезі. Також $\epsilon$ повідомлення про випадок тампонади серця у пацієнта 3 попереднім міоперикардитом в анамнезі. У літературі описуються і випадки фульмінантного міокардиту.

Гостре пошкодження нирок спостерігали у 4 \%, 3 приводу чого деяким хворим проводився гемодіаліз.

Смертність, яка пов'язана з COVID-19, чітко не визначена в міжнародних звітах, i відмінності у визначеннях того, що є смертністю, пов'язаною з COVID-19, можуть пояснити відмінності в показниках летальності серед різних країн. Загальний рівень смертності від COVID-19 набагато нижчий, ніж при SARS (10\%) і MERS (30\%). Однак COVID-19 в кінцевому підсумку виявився більш смертоносним, оскільки він поширився на набагато більшу кількість людей у всьому світі, ніж інші, внаслідок швидкої передачі вірусу від людини до людини i атипових симптомів на ранній стадії у деяких пацієнтів.

Частка важких або смертельних випадків може змінюватись залежно від місця. Несприятливі наслідки і смерть частіше зустрічаються у людей похилого віку та в осіб $з$ супутніми захворюваннями (50-75\% смертельних випадків). Більшість смертельних випадків мали місце у пацієнтів похилого віку або із важкими супутніми захворюваннями, включаючи 
серцево-судинні захворювання, цукровий діабет, хронічні захворювання легень, гіпертонію та рак. Середній термін від появи перших симптомів до смерті становив 14 днів, і він був коротшим серед пацієнтів у віці $\geq 70$ років $(11,5$ днів) в порівнянні з пацієнтами у віці <70 років (20 днів) [21].

Слід відмітити причинні фактори, що сприяють летальності. Деякі пацієнти, особливо важкохворі, мали спільне зараження бактеріями та грибками. Поширені бактеріальні культури пацієнтів із вторинними інфекціями включали A. baumannii, K. pneumoniae, A. flavus, C. glabrata та C. albicans. Високий рівень стійкості до антибіотиків A.baumannii може спричинити труднощі 3 протиінфекційним лікуванням, що призводить до більшої можливості розвитку септичного шоку. Для важких змішаних інфекцій, крім факторів вірулентності збудників, імунний статус господаря також $є$ одним з важливих чинників. Старість, ожиріння та наявність коморбідних захворювань можуть бути пов'язані зі збільшенням смертності.

\section{Висновки}

Нова коронавірусна інфекція яскраво висвітлила проблеми, що можуть раптово i одночасно виникати в багатьох країнах світу, коли з'являються нові інфекції, особливо, у випадках нехтування елементарними заходами профілактики. COVID-19 продемонструвала, яку колосальну шкоду може принести економіці різних країн спалах інфекції протягом короткого часу. 3 урахуванням нових інфекцій, необхідно докорінно переглянути ставлення до профілактичної медицини, біобезпеки країни, інфекційних хвороб та організації надання медичної допомоги при інфекційних захворюваннях.

Так як невідомі ні тривалість даної епідемії, ні кількість і час виникнення нових спалахів та епідемій, необхідно передбачити реконструкцію госпіталів/лікарень, де палати повинні бути боксованими, бажано зі зниженим тиском і окремим розміщенням хворих. При цьому слід передбачити розміщення хворих у палатах на безпечній дистанції, розділення між ліжками за допомогою ширм, умови для дотримання хворими правил особистої гігієни. Персонал повинен до всіх пацієнтів відноситись не тільки як до інфікованих на ВІЛ/СНІД чи гепатити, але як до хворих із гостро-заразними інфекціями, що передаються різними шляхами.

3 урахуванням того, що останніми роками серед військовослужбовців реєструються спалахи гостро-заразних інфекційних захворювань, необхідно у всіх інфекційних відділеннях створити боксовані палати, переглянути існуючі штати, удосконалити алгоритми переведення військових госпіталів і військових частин для роботи в умовах масового поступлення інфекційних хворих, в тому числі із гостро-заразними та особливо небезпечними інфекціями. Необхідно також вдосконалювати систему перепідготовки військових лікарів в умовах обмежених можливостей для прибуття до Української військово-медичної академії.

Слід передбачити створення мобільного інфекційного госпіталю 3 відповідним обладнанням, 3 можливістю розгортання в різних природних, метеорологічних умовах, 3 дотриманням рекомендацій щодо попередження виникнення внутрішньогоспітального спалаху та розповсюдження інфекції за межі госпіталю.

Нова коронавірусна хвороба має широкий спектр клінічних проявів, що значно ускладнює діагностику, з урахуванням недостатньої чутливості й доступності існуючих діагностичних методів. 3 урахуванням співпадіння сезону підвищеного ризику захворювання на коронавірусну інфекцію та ГРВІ, необхідно покращувати можливості діагностики завдяки різним методам. Це дуже важливо для військовослужбовців, які належать до групи підвищеного ризику таких захворювань.

У хворих із COVID-19 можуть розвиватися найрізноманітніші ускладнення, серед яких пневмонія, ГРДС, коагулопатія, тромбоемболія, ураження печінки. Тому у хворих зі швидким клінічним погіршенням слід виключати, крім розвитку ГРДС і легеневу тромбоемболію, в діагностиці якої важливу роль відіграють КТ-легенева ангіографія та додаткові лабораторні тести для дослідження системи коагуляції/антикоагуляції крові.

Під час епідемічного періоду COVID-19, при обстеженні пацієнтів з неврологічними та іншими проявами, лікарі повинні розглядати інфекцію SARS-CoV-2 у якості диференційного 
діагнозу задля уникнення відстроченого чи помилкового діагнозу, запобігання передачі, попередження летальних наслідків, особливо, при важкому її перебігу.

\section{References}

Література

1. [Electronic resource]. Available from: https://www.brookings.edu/blog/order-fromchaos/2020/04/22/covid-19-and-military-readiness-preparing-for-the-long-game/

2. [Electronic resource]. Available from: https://www.military.com/dailynews/2020/03/16/militarys-coronavirus-cases-latest-rundown.html

3. [Electronic resource]. Available from: https://undark.org/2020/05/07/military-covid-19/

4. [Electronic resource]. Available from: https://github.com/CSSEGISandData/COVID-19)

5. Sean Wei Xiang Ong. Air, Surface Environmental, and Personal Protective Equipment Contamination by Severe Acute Respiratory Syndrome Coronavirus 2 (SARS-CoV-2) From a Symptomatic Patient / Sean Wei Xiang Ong, Yian Kim Tan, Po Ying Chia, et al. / JAMA. - 2020. - Vol.323(16). - P.1610-1612.

6. Neeltje van Doremalen. Aerosol and Surface Stability of SARS-CoV-2 as Compared with SARS-CoV-1 / Neeltje van Doremalen, Trenton Bushmaker, Dylan H. Morris et al. // N Engl / Med. - 2020. Mar 17: NEJMc2004973. $\quad$ resource]. Alectronic from: https://www.ncbi.nlm.nih.gov/pmc/articles/PMC7121658/

7. Duan S.M. Stability of SARS coronavirus in human specimens and environment and its sensitivity to heating and UV irradiation / S.M. Duan, X.S. Zhao, R.F. Wen et al. // Biomed Environ Sci. - 2003. - Vol.16(3). P.246-55.

8. Kampf G. Persistence of coronaviruses on inanimate surfaces and their inactivation with biocidal agents / G. Kampf, D. Todt, S. Pfaender, E. Steinmann. [Electronic resource]. Available from: https://www.journalofhospitalinfection.com/article/S0195-6701(20)30046-3/fulltext

9. Bai Y. Presumed Asymptomatic Carrier Transmission of COVID-19 / Y. Bai, L. Yao, T. Wei et al. [Electronic resource]. Available from:https://jamanetwork.com/journals/jama/fullarticle/2762028

10. Nguyen H. Outbreak investigation for COVID-19 in northern Vietnam / H. Nguyen, T. Truong, N. Vana et al. [Electronic resource]. Available https://www.sciencedirect.com/science/article/pii/S1473309920301596

11. Wang J. Exploring the reasons for healthcare workers infected with novel coronavirus disease 2019 (COVID-19) in China / J. Wang, M. Zhou, F. Liu // Journal of Hospital Infection In Press, Journal Pre-proof What are Journal Pre-proof articles? [Electronic resource]. Available from: https://www.sciencedirect.com/science/article/pii/S01956701203 01018

12. Manal Al-Gethamy. A Case of Long-term Excretion and Subclinical Infection With Middle East Respiratory Syndrome Coronavirus in a Healthcare Worker / M. Al-Gethamy, V.M. Corman, R. Hussain et al. // Clinical Infectious Diseases. - 2015. - Vol.60 (6). - P.973-974.

13. Al-Tawfiq J.A. Asymptomatic Middle East Respiratory Syndrome Coronavirus (MERS-CoV) infection: Extent and implications for infection control: A systematic review / Jaffar A.Al-Tawfiq, Philippe Gautret / Travel Medicine and Infectious Disease. 2019. - Vol.27., - P.27-32.

14. Liu Y. Secondary attack rate and superspreading events for SARS-CoV-2 / Y. Liu, R.M. Eggo, A.J. Kucharski. (2020). [Electronic resource]. Available from: https://www.sciencedirect.com/science/article/pii/S0140673620304621

15. Lake M.A. What we know so far: COVID-19 current clinical knowledge and research / M.A Lake // Wellcome Trust clinical research training fellow. Clin Med (Lond). - 2020. - Vol.20(2). - P.124-127.

16. Adhikari S.P.. Epidemiology, causes, clinical manifestation and diagnosis, prevention and control of coronavirus disease (COVID-19) during the early outbreak period: a scoping review / S.P. Adhikari, S.Meng, Y.J. $\mathrm{Wu}$ et al. // Infect Dis Poverty. 2020; 9: 29. [Electronic resource]. Available from: https://www.ncbi.nlm.nih.gov/pmc/articles/PMC7079521/

17. Haider N. Passengers' destinations from China: low risk of Novel Coronavirus (2019-nCoV) transmission into Africa and South America / N.Haider, A.Yavlinsky, D.Simons et al. / Epidemiol Infect. - 2020. Vol.148: e41. [Electronic resource]. Available from: https://www.ncbi.nlm.nih.gov/pmc/articles/PMC7058650/

18. [Electronic resource]. Available from: https://www.statista.com/statistics

19. [Electronic resource]. Available from: https://health-infobase.canada.ca/covid-19/epidemiologicalsummary-covid-19-cases.html

20. Guan W.J. Clinical Characteristics of Coronavirus Disease 2019 in China / W.J. Guan, Z.Y. Ni, Y. Hu et al. (2020) // N. Engl. J. Med., Feb. 28, doi:10.1056/NEJMoa2002032.

21. Lai C.C. Severe acute respiratory syndrome coronavirus 2 (SARS-CoV-2) and coronavirus disease2019 (COVID-19): The epidemic and the challenges / C.-C. Lai, T.-P. Shih, W.-C. Ko et al. // International Journal 
of Antimicrobial Agents. - 2020. - Vol.55, Issue 3, March 2020, 105924. March 2020, 105924. [Electronic resource]. Available from:

https://www.sciencedirect.com/science/article/pii/S0924857920300674?via\%3Dihub

22. Wu X. Co-infection with SARS-CoV-2 and Influenza A Virus in Patient with Pneumonia, China / X. Wu, Y. Cai, X.Huang et al. [Electronic resource]. Available from: https://wwwnc.cdc.gov/eid/article/26/6/20$\underline{0299 \text { article }}$

23. Nanshan Chen. Epidemiological and clinical characteristics of 99 cases of 2019 novel coronavirus pneumonia in Wuhan, China: a descriptive study / Nanshan Chen, Min Zhou, Xuan Dong et al. [Electronic resource]. Available from: https://www.thelancet.com/journals/lancet/article/PIIS0140-6736(20)302117/fulltext].

24.Chen T. Clinical characteristics of 113 deceased patients with coronavirus disease 2019: retrospective study / T. Chen, D.Wu, H.Chen et al. Electronic resource. Available from: https://www.bmj.com/content/368/bmj.m1091

25. Tanu S. A Review of Coronavirus Disease-2019 (COVID-19) / S.Tanu // Indian J Pediatr. - Vol.87(4). P.281-286.

26. Klok F.A. Incidence of thrombotic complications in critically ill ICU patients with COVID-19 / F.A.Klok, M.J.H.A.Kruip, N.J.M.van der Meer, et al. [Electronic resource]. Available from: https://www.sciencedirect.com/science/article/pii/S0049384820301201

27. Huang C. Clinical features of patients infected with 2019 novel coronavirus in Wuhan, China / C. Huang, Y. Wang, $X . \quad \mathrm{Li}$ et al. Electronic resource. Available from: https://www.thelancet.com/journals/lancet/article/PIIS0140-6736(20)30183-5/fulltext

28. Mao L. Neurologic Manifestations of Hospitalized Patients With Coronavirus Disease 2019 in Wuhan, China / L. Mao, H.Jin, M.Wang et al. // [Electronic resource]. Available from: https://jamanetwork.com/journals/jamaneurology/fullarticle/2764549.

29. Cheung KS et al. Gastrointestinal manifestations of SARS-CoV-2 infection and virus load in fecal samples from the Hong Kong cohort and systematic review and meta-analysis. Gastroenterology 2020 Apr 3; [epub]. (https://doi.org/10.1053/i.gastro.2020.03.065).

\section{COVID-19. АКТУАЛЬНЕЙШАЯ ПРОБЛЕМА СОВРЕМЕННОСТИ}

\section{В.И. Трихлеб, Г.В. Оседло}

Украинская военно-медицинская академія, Киев

Введение. На сегодня, детальной информации относительно инфицирования военнослужащих в доступных источниках нет. В то же время есть информация о возможном инфицирования большого количества военных, особенно тех, которые находятся в условиях ограниченного пространства. Актуальность данной инфекции для военных заключается и в том, что во время призыва на военную службу, при возвращении из командировок и отпусков, данные категории лиц (особенно находящихся в инкубационном периоде или являются бессимптомными) могут занести nCoV 2019 в подразделение и вызвать возгорание.

Цель работы - изучение и обобщение опыта специалистов из разных стран по актуальным вопросам заболевания COVID-19.

Материалы и методы. С помощью исторического, библиосемантичного и сравнительного анализа и системного подхода проведено обобщение данных литературы по этиологических, эпидемиологических, клинических и диагностических аспектов новой коронавирусной инфекции, структуры и частоты осложнений.

Результаты. $B$ статье представлен обзор литературы $c$ отображением актуальности, этиологии, эпидемиологии, клинических проявлений, диагностических критериев COVID-19 и возможных осложнений, развивающихся при заболевании с такой частотой: пневмония (15,7-100\%), ОРДС (3-90\%), поражения сердца (миокардит и др. ), аритмия, токсический гепатит (4-53\%), реактивный панкреатит, тромбоз глубоких вен, тромбоэмболия (до 31\%), коагулопатия (до 38\%), анемия (до 15\%), острое поражение почек с развитием острой почечной недостаточности (3-8\%), сепсис, септический шок (4-8\%), полиорганная недостаточность, отит, синусит, бронхит, неврологические осложнения (36,4-45,5\%), острые цереброваскулярные заболевания, инсульт, нарушение сознания, атаксия, судороги, невралгия, травмы скелетных мыши, энцефалопатия, периферическая полинейропатия, вторичная бактериальная инфекция (6-10\%), бактериемия, грибковая суперинфекция, выкидыш (в 2\%), внутриутробное ограничение роста (в 10\%), преждевременные роды (в 39\%).

Выводы. У больных с COVID-19 могут развиваться самые разнообразные осложнения, среди которых пневмония, ОРДС, коагулопатия, тромбоэмболия, поражения печени. Поэтому у больных с 
быстрым клиническим ухудшением следует исключать, кроме развития ОРДС и легочную тромбоэмболию, в диагностике которой важную роль играют КТ-легочная ангиография и дополнительные лабораторные тесты для исследования системы коагуляции / антикоагуляции крови. Во время эпидемического периода COVID-19, при обследовании пациентов с неврологическими и другими проявлениями, врачи должны рассматривать инфекцию SARS-CoV-2 в качестве дифференциального диагноза во избежание отсроченного или ошибочного диагноза, предотвращения передачи, предупреждения летальных исходов, особенно, при тяжелом ее ход. Новая коронавирусная инфекция ярко осветила проблемы, которые могут внезапно и одновременно возникать во многих странах мира, когда появляются новые инфекции, особенно в случаях пренебрежение элементарными мерами профилактики. COVID-19 продемонстрировала, которую колоссальный вред может принести экономике различных стран вспышка инфекции в течение короткого времени. С учетом новых инфекций, необходимо в корне пересмотреть отношение к профилактической медищины, биобезопасности страны, инфекционных болезней и организации оказания медищинской помощи при инфекционных заболеваниях.

Ключевые слова: COVID-19, этиология, эпидемиология, клинические проявления, осложнения.

\title{
COVID-19. THE MOST RELEVANT PROBLEM OF OUR TIME
}

\author{
V.I. Trichleb, G.V. Osyodlo
}

Ukrainian Military Medical Academy, Kyiv

Introduction. To date, detailed information on the infection of servicemen is not available in available sources. At the same time, there is information about the possible infection of a large number of soldiers, especially those who are in a confined space. The relevance of this infection for the military is that when called up for military service, when returning from business trips and vacations, these categories of persons (especially those who are in the incubation period or are asymptomatic) can bring nCoV 2019 to the unit and cause an outbreak.

The purpose of the work is to study and summarize the experience of specialists from different countries on topical issues of COVID-19.

Materials and methods. Using historical, bibliosemantic and comparative analysis and a systematic approach, the literature data on the etiological, epidemiological, clinical and diagnostic aspects of new coronavirus infection, structure and frequency of complications are summarized.

Results. The article reviews the literature on the relevance of the disease, epidemiologic issues, clinical symptoms, possible complications of COVID-19 and their incidence: pneumonia (15,7-100\%), ARDS (3-90\%), heart damage (myocarditis, etc.), arrhythmia, toxic hepatitis (4-53\%), reactive pancreatitis, deep vein thrombosis, thromboembolism (up to 31\%), coagulopathy (up to 38\%), anemia (up to 15\%), acute kidney damage with the development of acute renal failure (3-8\%), sepsis, septic shock (4-8\%), multiple organ failure, otitis, sinusitis, bronchitis, neurological complications (36.4-45.5\%), acute cerebrovascular disease, stroke, cognitive impairment, ataxia, convulsions, neuralgia, skeletal muscle trauma, encephalopathy, peripheral polyneuropathy, secondary bacterial infection (6-10\%), bacteremia, fungal superinfection, miscarriage (2\%), intrauterine growth restriction (10\%) , premature birth (39\%).

Conclusions. Patients with COVID-19 can develop a variety of complications, including pneumonia, GRDS, coagulopathy, thromboembolism, liver damage. Therefore, in patients with rapid clinical deterioration, pulmonary thromboembolism should be ruled out, in addition to the development of GRDS, in the diagnosis of which CTpulmonary angiography and additional laboratory tests to study the blood coagulation / anticoagulation system play an important role. During the epidemic period of COVID-19, when examining patients with neurological and other manifestations, physicians should consider SARS-CoV-2 infection as a differential diagnosis to avoid delayed or misdiagnosis, prevent transmission, and prevent fatalities, especially in severe cases. . The new coronavirus infection has highlighted the problems that can arise suddenly and simultaneously in many countries around the world when new infections appear, especially in cases of neglect of basic prevention measures. COVID-19 has demonstrated the enormous damage that an outbreak of infection can do to the economies of different countries in a short period of time. In view of new infections, it is necessary to radically reconsider the attitude to preventive medicine, biosafety of the country, infectious diseases and the organization of medical care for infectious diseases.

Key words: COVID-19, etiology, epidemiology, clinical symptoms, complications.

Конфлікт інтересів: відсутній.

Conflicts of interest: authors have no conflict of interest to declare.

$A$ - концепція та дизайн дослідження; B - збір даних; $C$ - аналіз та інтерпретація даних; D написання статmi; $E$ - редагування статmi; F - остаточне затвердження статті 


\section{Відомості про авторів:}

Трихліб B.I., ${ }^{A-B C D}$ полковник медичної служби запасу, доктор медичних наук, професор кафедри військової терапії Української військово-медичної академії, м. Київ;

Осьодло Г.В., $C E F$ полковник медичної служби, доктор медичних наук, професор, начальник кафедри військової терапії Української військово-медичної академії, м. Київ

\section{Сведения об авторах:}

Трихлеб В.И., ${ }^{A-B} C D$ доктор медицинских наук, профессор кафедры военной терапии Украинской военно-медицинской академии, г. Киев;

Оседло Г.В., $C E F$ полковник медицинской службы, доктор медицинских наук, профессор, начальник кафедры военной терапии Украинской военно-медицинской академии, г. Киев.

\section{Information about authors:}

Trichleb V.I., $A-B C D$ MD DSc, Professor of the Department of Military Therapy of the Ukrainian Military Medical Academy, Kyiv, ORCID ID: 0000-0001-9250-4385

Osyodlo H.V., C F F Col. MS, MD DSc, Prof., Head of the Department of Military Therapy of the Ukrainian Military Medical Academy, Kyiv 